\title{
Dynamics of Jute Export in India
}

\author{
Kalpana Kumari ${ }^{1}$, Prashant Kumar Singh $^{2}$, Swati Kumari ${ }^{3 *}$ and Krishna Murari Singh ${ }^{1}$ \\ ${ }^{1}$ Department of Agricultural Economics, Dr. Rajendra Prasad Central Agricultural \\ University, Pusa, Samastipur-848125, India \\ ${ }^{2}$ Department of Agricultural Economics, Banaras Hindu University, Varanasi-221005, India \\ ${ }^{3}$ Bihar Agricultural University, Sabour, Bhagalpur-813210, India \\ *Corresponding author
}

\section{Keywords}

Jute, Export, Growth trend, Decomposition analysis, Trend analysis, Rank based quotient

\section{Article Info}

Accepted:

26 May 2020

Available Online:

10 June 2020

\begin{abstract}
A B S T R A C T
The dynamics of export of Jute quantity in India was studied taking into account time series data from 1990-91 to 2015-16 with an aim to assess production factor variability and constraints faced by Jute farmers so as to suggest a plausible solution to turn Jute farming into a more profitable venture. The Jute export registered a significant positive growth trend of $6.90 \%$ annum $^{-1}$. The entire period for which the study was conducted was divided in to three sub-periods of 10 years (1990-1991 to 1999-2000), 10 years (2000-2001to 2009-2010) and 06 years (2010-2011 to 2015-2016). During these sub-periods the trend in export of Jute found to be fluctuating. The negative growth rate $(-22.50 \%)$ was observed for Jute export during the entire period of study. The overall instability in export during the entire period is reflected by coefficient of variation that was $76.57 \%$. Rank Based Quotient (RBQ) for constraints faced by Jute growers of West Bengal, a major Jute producing state, revealed lack of organised market as major constraint (RBQ 92.15) followed by high labour cost (RBQ 90.76) that thwart farmers from taking up Jute farming. Thus, based on the present study it can be concluded that the export over the years are dwindling that could probably be ameliorated by addressing the above cited two major constraints that Jute growing farmers of West Bengal face.
\end{abstract}

\section{Introduction}

Jute (Chorchorus spp.) is a dicotyledonous fiber crop that belongs to family Tiliaceae and genus Chorchorus. Jute fibre is a natural fiber that is also nick named as 'golden fiber'. Jute is cheapest and most important of all textile fibers next to cotton (Gossypium spp.) and is used widely in manufacturing different types of packaging materials for various agricultural and industrial products. Jute fiber is obtained from two commercially important species namely, White jute (Corchorus capsularis) and Tossa Jute (Corchorus olitorius).

Jute is however, our potential foreign exchange earner and must finds its place in our economy. It is estimated that more than 4 million farm families are engaged in jute farming and majority of them belongs to 
small and marginal categories. Besides, 0.5 million people are involved in raw jute and finished good trading and ancillary activities. Raw jute production in India is expected to touch 10.2 million bales $(1 \mathrm{bale}=180 \mathrm{~kg})$ this year with $25-30 \%$ increase in sowing area of fiber crops (Source: FAO 2017).

Jute Cultivation is dependent on climate, season and soil. Almost $85 \%$ of world's Jute cultivation is concentrated in the Ganges delta. This fertile geographic region is shared by both Bangladesh and India.

China also has a dominating place in cultivation of jute. Several other countries like, Thailand, Myanmar, Pakistan, Nepal and Bhutan also cultivate jute and allied fibres on a smaller scale. Jute and allied fibers are group of natural fibers which have inconceivable economic and trade importance particularly in West Bengal, India.

The area under jute in India is around 7.9 lakh ha with a production of about 102.85 lakh bales. West Bengal contributes the maximum towards Jute cultivation and it shares about $74.7 \%$ and $81.6 \%$ of national acreage and production, respectively (five years average of 2006-07 to 2010-2011). Jute is the cash crop for the poor and the marginal farmers in India and it continues to be an important commodity for employment and source of income for them. To meet the demands of the industry, production of jute and allied fibers have to be increased.

Two important means to achieve this is to increase the output and to increase the area covered under jute cultivation. With the continuous efforts of the scientists as well as the special programs for jute production implemented by the Government, the area and productivity of jute had improved tremendously. Even then the jute sector could not be revived to the fullest extent. The industry faced stiff competition from its cheaper substitutes. The farmers on the other hand are not receiving remunerative price for the fiber they produce. It is therefore imperative to sort out the problems to the extent possible and bring back the past glory of jute production in India.

\section{Materials and Methods}

\section{Source of data}

The study was purely based on secondary data. The data was collected from www.Indiastat.com Government of India of year 1990-91 to 2015-16, Directorate of Economics and Statistics, Food and Agriculture Organisation and National Jute Board.

\section{Methodology}

The data regarding area, production and yield of jute in India were collected for last 26 years i.e. from 1990 to 2016.The whole period of study has been divided into three sub-periods i.e. Period I (1990 to 2000), Period II (2000 to 2010), Period III (20102016) and overall period (1990 to 2016).

On the basis of the data collected for this period, Compound growth rates, Means, Standard Deviations and analysis of instability in area, production and productivity of jute were estimated to examine the fluctuation.

\section{Estimation of growth rate}

Growth rate are worked out to examine the tendency of variable to increase, decrease or stagnant over a period of time. It also indicates the magnitude of the rate of change in the variable under consideration per unit of time. The rate of change of "Y $t$ " per unit of time to express as a function of the magnitude 
of "Yt" itself is usually termed as the compound growth rate (CGR) which can be expressed mathematically as:

$$
\begin{aligned}
\operatorname{CGR} & =\left[\left(\frac{1}{V t}\right)\left(\frac{d Y t}{d t}\right)\right] \\
& =\left[\left(\frac{Y t+1-Y t}{Y t}\right)\right]
\end{aligned}
$$

The above expression if multiplied by 100 gives the compound growth rate of $\mathrm{Yt}^{\mathrm{ee}}$ in percentage term. There are many alternative forms of growth function viz., linear exponential, modified exponential, CobbDouglas etc. which have been developed and used by the researcher.

The mathematical form of log-linear function (also known as exponential function) is as follows:

$$
\mathrm{Yt}=A e^{b t}
$$

The log transformation of this is as follows :

$\log e Y t=\log _{e} A+b t$

Differentiating it with reference to " $t$ " gives,

$$
\left[\left(\frac{1}{Y_{t}}\right)\left(\frac{d Y_{t}}{d_{t}}\right)\right]=b
$$

Or,

$$
\frac{d Y_{t}}{d_{t}}=b Y_{t}
$$

The formula for calculating Compound Growth Rate (CGR) from the log linear equation can be derived as follows:

Let "Y0" be the value of variable under study in the base period.
"Yt" be the value of variable in time " $\mathrm{t}$ ".

"Y" be the value of Compound Growth Rate (CGR) then using the compounding formula, We get,

$\mathrm{Yt}=\mathrm{Y} 0(1+\mathrm{r}) \mathrm{t}$

Log - transformation of the above i.e.

$\log \mathrm{Yt}=\log \mathrm{Y} 0+\mathrm{t} \log (1+\mathrm{r})$

Assuming

$$
\begin{aligned}
& \log Y 0=\log A . \\
& \log (1+r)=b,
\end{aligned}
$$

The same expression can be put as-

$$
\log \mathrm{Yt}=\log \mathrm{A}+{ }^{b^{t}}
$$

From the log-linear form, CGR can be worked out as follows:

By differentiating,

$$
\frac{\mathrm{d}(\log Y \mathrm{t})}{\mathrm{dt}}=\mathrm{b} .
$$

But, the estimate of " $b$ " in the log-linear function is in semi-log terms. Therefore, to convert it into the original form of $\mathrm{Yt}$ following transformation is done

Since, $b=\log (1+r)$

Antilog (b) $=1+r$

$r=($ Antilog “b”) -1

CGR in percentage $=[($ Antilog “ $b ")-1] \mathrm{x}$ 100

\section{Measurement of instability}

Instability is the deviation from the trend. It can be measured by using co-efficient of variation. The standard deviation as percentage of means called as co-efficient of variation.

$\mathrm{CV}=\stackrel{\sigma}{\mu} \times 100$ 
Where, $\mathrm{CV}=$ Co-efficient of variation $\sigma=$ Standard deviation of the variable $\mu=$ Mean of the variable.

\section{Results and Discussion}

\section{Compound growth trend in jute export quantity in India}

The compound growth trend equations were fitted to assess growth trend in export quantity of Jute. To assess the trends in export quantity, the data over the period from 1990 to 2016 were considered.

It could be seen from the analysis that export of the commodity was inconsistent in overall period.The jute export was 6250 tons in 1990 and it was increased to a level of 10934 tonn in 2015-16 with fluctuating export growth rate concerning the years during different periods. The growth trend analysis of jute export registered a significant and positive growth trend of 6.9 per cent per annum.
During second period (2000-2010), compound growth rate was observed to be highest that is 20.1 per cent per annum and lowest CAGR was 22.5 per cent which was in decreasing trend during third period of study (2010-2016). In first period (1990-2000) of study compound growth trend was 1.5 per cent per annum only, which shows a fluctuating trend in compound growth rate of export of jute in overall period (Table 1). A perusal of Table 1indicates compound growth rate of export of jute in India.

\section{Instability analysis of Jute}

In order to study the instability in the export of jute quantity in India during the study period, coefficient of variation was worked out. The total period (1990-2016) was split into three sub periods viz., period I (19902000), period II (2000-2010) and period III (2010). The instability refers to the deviation from a particular trend .It indicates the extent of variability.

Table.1 Compound growth trend in export of jute in India

\begin{tabular}{|c|c|c|c|c|c|}
\hline Items & Particulars & $\begin{array}{c}\text { Period 1 } \\
(\mathbf{1 9 9 0 - 0 0 )}\end{array}$ & $\begin{array}{c}\text { Period 2 } \\
(\mathbf{2 0 0 0 - 1 0 )}\end{array}$ & $\begin{array}{c}\text { Period 3 } \\
(\mathbf{2 0 1 0 - 1 6 )}\end{array}$ & $\begin{array}{c}\text { Over all } \\
\text { period }\end{array}$ \\
\hline \multirow{3}{*}{ Export } & F value & 1.73 & 23.82 & 3.42 & 28.52 \\
\cline { 2 - 7 } & $\mathbf{R}^{2}$ & 0.17 & 074 & 0.46 & 0.54 \\
\cline { 2 - 7 } & CGR & 1.5 & $20.1 * * *$ & -22.5 & $6.9^{* * *}$ \\
\hline
\end{tabular}

CGR-Compound growth rate percent per annum. ***- Significant at $1 \%$ level of significance;

$*_{*}^{*}$-Significant at $5 \%$ level of significance; *-Significant at $10 \%$ level of significance

Table.2 Instability analysis of area, production and productivity of jute in India

\begin{tabular}{|c|c|c|c|c|c|}
\hline \multirow{2}{*}{ Items } & Particulars & $\begin{array}{c}\text { Period I } \\
(\mathbf{1 9 9 0 - 0 0 )}\end{array}$ & $\begin{array}{c}\text { Period II } \\
\mathbf{( 2 0 0 0 - 1 0 )}\end{array}$ & $\begin{array}{c}\text { Period III } \\
\mathbf{( 2 0 1 0 - 1 6 )}\end{array}$ & Overall \\
\hline \multirow{2}{*}{ Export } & SD & 819.90 & 14614.15 & 13862.26 & 13750.56 \\
\cline { 2 - 7 } & Mean & 7526.2 & 22853.8 & 27177.66 & 17956.38 \\
\hline & CV & $10.89 \%$ & $63.94 \%$ & $51.00 \%$ & $76.57 \%$ \\
\hline
\end{tabular}

SD : Standard deviation; CV: Co-efficient of variation

Table 2 reveals that the overall variability found in jute quantity export was 76.57 per cent. During first, second and third period under study variability was observed to be 
10.89 percent, 63.94 per cent and 51 per cent respectively. The highest variability was observed in second period (2000-2010) that is 63.94 per cent.

The data collected for the 26 years from 1990-2016 were divided into three sub periods of 10,10 and 6 years respectively, period I (1990-2000), period II (2000-2010) and period III (2010-2016) for easy calculation of the objectives needed.

The Compound growth rate was used to find out the growth trend in export of jute in India. The coefficient of variation was used to find out the variability in export quantity of jute.

The growth trend analysis of jute export registered a significant and positive growth trend of 6.9 percent per annum. During second period (2000-10), compound growth rate was observed to be highest that is 20.1 percent per annum and lowest CAGR was 22.5 percent which was in decreasing trend during third period of study (2010-16).

In first period (1990-2000) of study compound growth trend was 1.5 percent per annum only, which shows a fluctuating trend in compound growth rate of export of jute in overall period. As far as the export quantity of jute is concerned, the overall variability was 76.57 percent.

During first, second and third period under study variability was observed to be 10.89 percent, 63.94 percent and 51 percent respectively. The highest variability was observed in second period (2000-10) that is 63.94 percent.

India is the second largest producer of jute in the world. Indian jute was slowly covering the international market. In order to maintain the maintain the comparative advantages, Indian jute industry needs improvement in research facility and modern technology. there is a need to increase the yield levels which ultimately helps in increase in domestic production and can gain good foreign exchange through export.

The export parameters under study have significantly shown a fluctuating trend over the years. Increase in export business helps in scarce foreign exchange and stimulate the domestic industries to manufacture the quality product.Agricultural pricing policy plays a key role in increasing both farm production and incomes. Findings from this research paper are not only an initial effort from this perspective but also provide future issue for research and suggest necessary policy guidelines for future production and marketing strategies of the country.

\section{References}

Annual Report (2016-17) Ministry of textile, Government of India

Chinnappa, B. and T.R. Keshava Reddy (April- June, 1999), "An Empirical Analysis of Growth and Instability in Sugar Industry", Agricultural Banker, Vol. 23(2), 27-33.

Das, B. B. and Goswamy, K. K. (2001). Jute and Mesta statistics a critical analysis. All India Coordinated Research Project on Jute and Allied Fibers, Barrackpore.

Das, M. And Chanu, L. A. (2016). Farmers' share in consumers' price in jute marketing with reference to jute farmers of Barpeta District of Assam. Indian Journal of Applied Research. 6(4):235 238.

Das, M. and Chanu, L. A. (2016).Farmer's share in consumers' price in jute marketing with reference to jute farmers of Barpeta District of Assam. Indian Journal of Applied Research. 6(4): 235238.

Dayal, R. (1966). Agricultural Growth Rates 
and Their Components. Indian Journal of Agricultural Economics. 21 (4): 227 237.

FAO: "Demand outlook for jute and Policy implication" in FAQ Publication, (1990),(Commodities and Trade Division), Rome, P. 10. 18A.

Goyal, H.D. (1990). Indian Jute Industry, problems and Prospects. Delhi: Common wealth Publishers. 6-7

Karthik, G. and Ramya, N(2012). Swot Analysis of Indian Jute industry. Indian Streams Research Journal. 2: 10-14.

Khan, Azizur Rahman (1961), Problems of Jute Marketing in East Pakistan, The Pakistan Development Review, Vol. 1, No. 2- 78

Mishra, V.N. (1971). Growth of Crop Output in Gujarat: A Component Analysis.

N.D. web Rao, N. K. Muralidhara \& Ramaswamy, P. (1974): "Raw Jute Marketing:

Narain, Dharm. (1977), Growth of Productivity in Indian Agriculture. Indian Journal of Agricultural Economics. 32(2): 20-32.

National Jute policy, (2016-17), Report on jute 2016-17 Government of India.

Pal, Anusri and Chakraborti, Pinaki (2011), Indian Jute Industry in the Globalisation Era: Structure and Performance, Economic \& Political Weekly EPW march 5, 2011 Vol 11(6), 93-100.

Problems and Solutions" Economic and Political Weekly March 23 497-488

Rahim, et al., (1977): "The future of Jute in Bangladesh: An Analysis of Some Policy Issues" in Bangladesh Economy: Problems and Issues/ (Dhaka: Dhaka University Press).

Rahman, Sultan Hafeez, (1987) an Analysis of Seasonal Jute Price Behaviour, the Bangladesh Development Studies, Vol. 15, No. 3 43-61.

Singh, M.(2014). Status paper: Status of raw jute (Jute and Mesta) in India. Directorate of Jute Development, Ministry of Agriculture, Department of Agriculture and Cooperation, Government of India. V01 43(2), 226234.

Verma C. (Jan. 1987), "Domestic Demand for Jute Goods in India" in Ilarqin, P. 35.

\section{How to cite this article:}

Kalpana Kumari, Prashant Kumar Singh, Swati Kumari and Krishna Murari Singh. 2020. Dynamics of Jute Export in India. Int.J.Curr.Microbiol.App.Sci. 9(06): 3769-3774. doi: https://doi.org/10.20546/ijcmas.2020.906.xx 